\title{
Pengaruh Gaya Belajar Terhadap Penguasaan Konsep Fisika Siswa Pada Materi Besaran dan Pengukuran
}

\author{
Syahriani Yulianci ${ }^{1, *}$, Gunawan $^{2}$, Aris Doyan $^{2}$, Fenny Febriyanti $^{1}$ \\ ${ }^{1}$ STKIP Taman Siswa Bima \\ ${ }^{2}$ Univeristas Mataram \\ *syahrianiyulianci@unram.ac.id
}

Artikel Info

Tanggal Publikasi

$2019-12-30$

\section{Kata Kunci}

Gaya Belajar

Penguasaan Konsep

Fisika

Besaran dan Pengukuran

\begin{abstract}
Abstrak
Gaya belajar merupakan salah salah satu cara yang biasa digunakan siswa dalam menerima atau mengolah informasi yang diperoleh. Penelitian ini bertujuan menguji pengaruh gaya belajar terhadap penguasaan konsep fisika siswa. Penelitian ini merupakan penelitian eksperimen semu dengan desain pretest-posttest control group. Subjek penelitian berjumlah 68 siswa yang diperoleh secara purposive sampling. Subjek penelitian dibagi ke dalam tiga kelompok berdasarkan gaya belajar masing-masing yaitu kelompok visual, kelompok auditrori, dan kelompok kinestetik. Terdapat dua data yang diperoleh dalam penelitian ini yaitu data gaya belajar dan data penguasaan konsep fisika pada materi besaran dan pengukuran. Data gaya belajar diperoleh melalui instrument gaya belajar dengan jenis pilihan ganda berjumalah 20 butir soal. Instrumen penguasaan konsep fisika sebanyak 22 butir soal berbentuk pilihan ganda. Data dianalisis dengan menggunakan uji statistik Anava Dua Jalur. Hasil uji statistik memperlihatkan bahwa gaya belajar tidak berpengaruh secara signifikan terhadap penguasaan konsep fisika siswa. Hal ini dibuktikan dari nilai rata-rata posttest penguasaan konsep fisika ketiga jenis gaya belajar memiliki nilai yang hampir sama.
\end{abstract}

\section{PENDAHULUAN}

Gaya belajar merupakan salah satu karaktersitik belajar yang berkaitan dengan menyerap, mengolah, dan menyampaikan informasi. Sehingga gaya belajar merupakan modalitas utama dalam belajar. Gaya belajar menurut Kolb (2005) adalah cara yang cenderung dipilih seseorang untuk menerima informasi dalam lingkungannya dan memproses informasi. Belajar membutuhkan konsentrasi, oleh karena itu situasi dan kondisi untuk berkonsentrasi sangat berhubungan dengan gaya belajar. Apabila setiap individu dapat mengelola pada kondisi apa, di mana, kapan dan bagaimana gaya belajarnya, maka belajar akan lebih efektif dan efisien sehingga hasil belajar lebih tinggi.

Secara umum ada tiga kecenderungan gaya belajar antara lain gaya belajar visual, auditori, dan gaya belajar kinestetik. Jika seorang peserta didik memiliki gaya belajar visual maka akan lebih senang dan cepat memahami apabila suatu materi dijelaskan dengan menggunakan tampilan visual. Peserta didik yang memiliki gaya belajar auditori akan senang dan lebih mudah memahami materi jika disajikan dengan suara. Berbeda halnya dengan gaya belajar kinestetik, peserta didik yang memiliki gaya belajar kinestetik akan lebih senang dan mudah memahami jika belajar dengan bergerak, menyentuh, atau melakukan sesuatu.

Salah satu hasil yang sangat diharapkan dalam pembelajaran fisika adalah penguasaan konsep fisika. Konsep merupakan dasar bagi proses mental yang lebih tinggi untuk merumuskan prinsip dan generalisasi. Untuk memecahkan masalah, seorang peserta didik harus mengetahui aturan-aturan yang relevan dan aturan-aturan ini didasarkan pada konsep-konsep yang diperolehnya (Dahar, 2011).

Penguasaan konsep fisika merupakan ukuran kemampuan dari peserta didik dalam menguasai konsep-konsep fisika yang diajarkan. Penguasaan konsep fisika termasuk dalam hasil belajar pada ranah 
kognitif. Ranah kognitif dari hasil belajar menurut Bloom meliputi penguasaan konsep, ide, pengetahuan faktual, dan berkenaan dengan keterampilan-keterampilan intelektual. Syahriani (2017) penguasaan konsep bukan hanya sekedar memahami tetapi dapat menginterpretasikan ataupun mengaplikasikan konsep-konsep yang telah diperoleh.

Gunawan et al. (2016) menemukan bahwa gaya belajar dapat mempengaruhi penguasaan konsep fisika peserta didik pada materi kalor, di mana peserta didik yang memiliki gaya belajar visual memiliki penguasaan konsep yang lebih tinggi jika dibandingkan dengan peserta didik yang memiliki kecenderungan gaya belajar auditori ataupun kinestetik. Berdasarkan pemaparan di atas maka pembahasan artikel ini bertujuan untuk mengetahui pengaruh gaya belajar terhadap penguasaan konsep fisika peserta didik.

\section{METODE PENELITIAN}

Penelitian ini termasuk dalam jenis eksperimen semu. Desain penelitian yang digunakan adalah pretest-posttest control group. Subjek penelitian sebanyak 68 siswa yang diperoleh secara purposive sampling. Data gaya belajar diperoleh sebelum dilakukannya pretest. Instrument gaya belajar berupa tes tertulis dengan bentuk pilihan ganda sebanyak 20 butir soal. Di tiap butir soal terdapat masing-masing 3 pilihan jawaban, yang hanya akan dipilih satu oleh siswa. Sedangkan data penguasaan konsep diperoleh saat prestest dan posttest. data dianalisis menggunakan uji Anava Dua Jalur.

Instrumen penguasaan konsep fisika digunakan untuk mengukur penguasaan konsep fisika pada materi besaran fisika dan pengukuran. Penyusunan instrument mengikuti ranah kognitif yang ditemukan oleh Bloom revisi Anderson, sehingga soal-soal yang dibuat mengacu pada ranah kognitif C1 (mengingat), C2 (memahami), C3 (mengaplikasikan), C4 (menganalisis), C5 (menilai) dan C6 (mengaplikasikan). Sub materi besaran fisika dan pengukuran yang diteliti antara lain besaran dan satuan, besaran pokok dan besaran turunan, notasi ilmiah, angka penting dan pengukuran.

\section{HASIL DAN PEMBAHASAN}

Penelitian ini memperoleh dua data yaitu data gaya belajar dan data penguasaan konsep fisika siswa. Berdasarkan Tabel 1, tipe gaya belajar yang mendominasi pada subjek penelitian adalah gaya belajar auditori yaitu sebanyak 34 siswa, sedangkan untuk gaya belajar visual dan kinestetik masingmasing sebanyak 23 siswa dan 11 siswa.

Tabel 1. Data Gaya Belajar Siswa

\begin{tabular}{lcc}
\hline \multicolumn{1}{c}{ Gaya Belajar } & Jumlah & Persentase (\%) \\
\hline Visual & 23 & 34,00 \\
Auditori & 34 & 50,00 \\
Kinestetik & 11 & 16,00 \\
\hline
\end{tabular}

Nilai rata-rata penguasaan konsep berdasarkan gaya belajar peserta didik pada Gambar 2 memperlihatkan bahwa secara keseluruhan terdapat peningkatan. Peningkatan tertinggi dicapai oleh siswa yang memiliki gaya belajar auditori, sedangkan peningkatan terendah dicapai oleh siswa yang memiliki gaya belajar kinestetik. Terlihat nilai yang diperoleh saat posttest ketiganya memiliki nilai ratarata yang hampir sama.

Selain itu data gaya belajar dan penguasaan konsep diuji secara statistik menggunakan uji Anava Dua Jalur. Hasil diperoleh nilai F sebesar 0,184 dengan signifikansi 0,833>0,05; sehingga $\mathrm{H}_{\circ}$ diterima dan $\mathrm{H}_{\mathrm{a}}$ ditolak. Dengan demikian hasil pengujian hipotesis adalah tidak terdapat pengaruh gaya belajar terhadap penguasaan konsep fisika peserta didik. Hasil penelitian ini tidak sejalan dengan beberapa hasil penelitian sebelumnya di antaranya Ramlah et al. (2014) yang menunjukkan bahwa adanya pengaruh yang signifikan antara gaya belajar, terhadap prestasi belajar. Gunawan et al. (2016) 
menunjukkan bahwa penguasaan konsep dipengaruhi oleh gaya belajar, di mana siswa dengan gaya belajar visual memiliki penguasaan konsep yang lebih tinggi dibandingkan siswa dengan gaya belajar lainnya. Nurmayani (2016) pada hasil penelitiannya menunjukkan bahwa nilai rata-rata kelompok siswa yang memiliki kecenderungan gaya belajar kinestetik lebih tinggi dibandingkan dengan gaya belajar visual dan auditori.

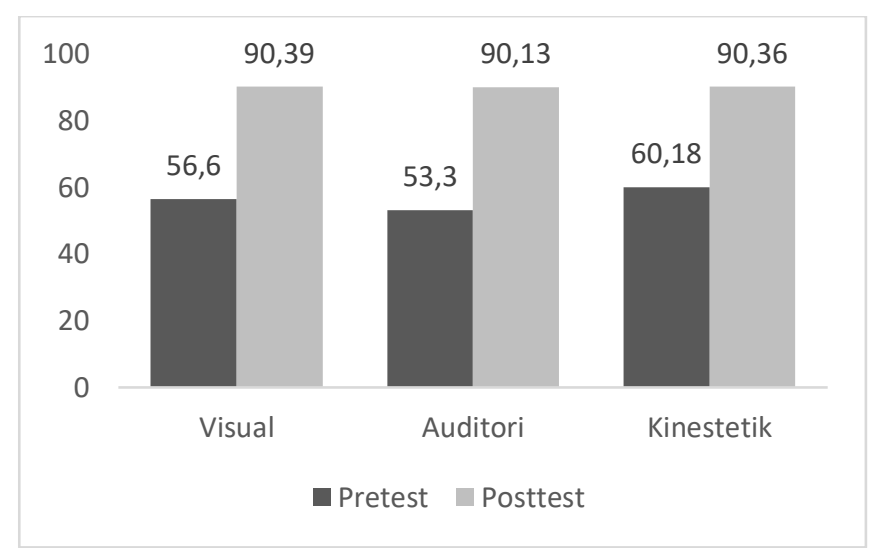

Gambar 1. Perbandingan nilai rata-rata Penguasaan Konsep Fisika Siswa berdasarkan gaya belajar

Gaya belajar merupakan suatu cara yang dirasa nyaman oleh seseorang untuk mendapatkan atau mengolah informasi. Sehingga seharusnya dengan mengetahui gaya belajar maka seseorang dapat lebih mudah mempelajari informasi yang diinginkan. Tetapi dalam penelitian ini memberikan hasil yang bersimpangan dengan teori-teori yang telah dipopulerkan oleh beberap ahli. DePorter (2008) mendefinisikan gaya belajar adalah kombinasi dari bagaimana seseorang menyerap dan kemudian mengatur serta mengolah informasi. Sehingga peserta didik yang memiliki gaya belajar tertentu akan mampu mengatur informasi secara maksimal yang diproses dalam kognitif siswa. Gaya belajar merupakan metode yang diterapkan oleh masing-masing individu dalam berinteraksi dengan lingkungannya dalam rangka memperoleh, memproses, menafsirkan informasi yang bermanfaat bagi pengalaman atau keterampilan yang diinginkan (Fleming, 2006). Pritchard (2009) juga mendefiniskan gaya belajar sebagai cara belajar yaitu cara-cara terbaik yang lebih disukai oleh seseorang dalam melakukan kegiatan berfikir, memperoleh dan memproses informasi, dan menunjukkan proses belajarnya. Berdasarkan ketiga definisi gaya belajar tersebut sudah seharusnya gaya belajar dirasa cukup berpengaruh terhadap hasil belajar ataupun proses pencapaian tujuan pembelajaran (Muhaimin, 2013).

Syamsu (2015) Mengoptimalkan gaya belajar yang dimiliki oleh siswa dapat dilakukan beberapa hal sesuai tipe gaya belajar antara lain: (1) Siswa Visual dengan cara menunjukkan beberapa gambar yang menarik serta peta konsep (2) Siswa Auditorial dengan cara mengulang-ulang materi yang dianggap penting (3) Siswa Kinestetik; merancang suatu model pembelajaran yang lebih membuat siswa lebih banyak beraktivitas seperti pembelajaran berbasis proyek, metode demonstrasi maupun praktikum.

Gaya belajar yang diukur dalam penelitian ini adalah gaya belajar visual, auditori, dan kinestetik. Peserta didik bisa saja memiliki lebih dari satu gaya belajar, artinya mungkin saja memiliki dua kecenderungan gaya belajar, tetapi hanya akan ada satu yang sangat mendominasi dari gaya belajarnya. Selama proses peembelajaran guru telah mendesain sedemikian rupa agar pembelajaran di rasa adil oleh tiap peserta didik yang memiliki kecederungan gaya belajar yang berbeda-beda tanpa mendominasi untuk hanya mendukung satu gaya belajar dalam proses pembelajarannya.

Peneliti menduga terdapat beberapa faktor sehingga gaya belajar tidak berpengaruh pada penguasaan konsep fisika peserta didik. Hal ini bisa terjadi, pertama; peneliti menduga bahwa pertanyaan -pertanyaan yang terdapat dalam instrumen gaya belajar yang digunakan belum sesuai untuk memberikan informasi yang jelas tentang jenis gaya belajar peserta didik, sehingga kesalahan dalam menganalisis hasil tes gaya belajar peserta didik bisa terjadi. Kedua; peserta didik tidak serius dalam 
mengisi instrumen gaya belajar yang diberikan, sehingga guru ketika menganalisis pengaruh gaya belajar mereka terhadap penguasaan konsep tidak sesuai dengan yang diharapkan. Ketiga ; jika ditinjau saat pemberian test awal dan tes akhir, Di luar pengawasan guru, mungkin saja peserta didik melihat jawaban peserta didik lainnya, sehingga akan sama nilai antara peserta didik dengan gaya belajar yang berbeda tersebut.

Tidak adanya pengaruh gaya belajar terhadap penguasaan konsep fisika, selain beberapa penyebab yang telah dipaparkan diatas, Yulianci (2017) menyebutkan beberapa alas an di antaranya diduga bahwa terjadinya karena adanya kegiatan pengelompokkan dalam proses pembelajaran, sehingga tidak menutup kemungkinan peserta didik dengan gaya belajar yang berbeda dan nilai kemampuan awal yang berbeda akan saling bercampur, berdiskusi, sehingga mereka dapat bertukar pikiran dan memiliki keterampilan dan pemahaman yang sama. Sehingga pada saat melakukan tes penguasaan konsep fisika, peserta didik dengan gaya belajar yang berbeda memiliki nilai yang hampir sama ataupun peningkatan kemampuan yang sama, sehingga hal inilah yang menyebabkan tidak terlihatnya pengaruh gaya belajar terhadap penguasaan konsep fisika peserta didik.

\section{KESIMPULAN}

Berdasarkan hasil analisis data dan pembahasan, maka dalam penelitian ini dapat disimpulkan bahwa gaya belajar tidak berpengaruh secara signifikan terhadap penguasaan konsep fisika siswa. Saran untuk peneliti selanjutnya, jika ingin menggunakan varibel gaya belajar, perlu adanya revisi kembali mengenai instrument yang akan digunakan atau dapat digunakan juga dengan menambah bentuk sumber informasi gaya belajar seperti wawancara secara langsung dengan peserta didik untuk benarbenar memastikan kecenderungan gaya belajar mereka.

\section{Daftar Pustaka}

Dahar, R.W. 2011. Teori-Teori Belajar dan Pembelajaran. Bandung : Erlangga.

De Porter, B., Mark, R., \& Sarah. 2014. Quantum Teaching. Bandung : PT Mizan Pustaka.

Fleming, N. 2006. Teaching and Learning Styles. VARK Strategies. New Zealand, Christchurch : Microfilm Ltd.

Gunawan, G., Harjono, A., \& Imran, I. 2016. Pengaruh Multimedia Interaktif dan Gaya Belajar Terhadap Penguasaan Konsep Kalor Siswa. Jurnal Pendidikan Fisika Indonesia, 72(2), 118-125.

Kolb, A.Y \& Kolb, D.A. 2005. Learning Styles and Learning Spaces : Enhancing Experiential Learning in Higher Education. Academy of Management Learning EE Education, 4(2), 193-212.

Muhaimin, A. 2013. Pengembangan Media Tiga Dimensi Kapasitor (MTDK) dan Pengaruhnya Terhadap Pemahaman Konsep, Sikap Ilmiah, dan Keterampilan Proses Sains Ditinjau dari Gaya Belajar Siswa SMK. Tesis Pascasarjana : Universitas Mataram.

Nurmayani, N., \& Syuaib, M. Z. (2017). Pengaruh Gaya Belajar VAK pada Penerapan Model Pembelajaran Problem Based Learning Terhadap Hasil Belajar IPA Fisika Siswa SMP Negeri 2 Narmada Tahun Ajaran 2015/2016. Jurnal Pendidikan Fisika dan Teknologi, 2(1), 13-21.

Pritchar, A. 2009. Ways of Learning: Learning Theories and Learning Styles in The Classroom. Second Edition. New York : Routlegde Taylor \& Francise Library

Ramlah., Firmansyah, D., \& Zubair, H. 2014. Pengaruh Gaya Belajar dan Keaktifan Siswa Terhadap Prestasi Belajar Matematika (Survey pada SMP Negeri di Kecamatan Klari Kabupaten Karawang). Journal Ilmiah solusi. 
Rijal, S., \& Bachtiar, S. (2015). Hubungan antara Sikap, Kemandirian Belajar, dan Gaya Belajar dengan Hasil Belajar Kognitif Siswa. Jurnal Bioedukatika, 3(2), 15-20.

Yulianci, S., Gunawan, G., \& Doyan, A. (2017). Model Inkuiri Terbimbing Berbantuan Multimedia Interaktif Untuk Meningkatkan Penguasaan Konsep Fisika Peserta Didik. Jurnal Pendidikan Fisika dan Teknologi, 3(2), 146-154.Yulianci (2017)

Yulianci, S., Gunawan, G., \& Doyan, A. (2017). The Effect of Guided Inquiry Model with Interactive Multimedia Towards Student's Generic Science Skill Based on Learning Styles. 